\title{
Vascular Incorporation of $\alpha$-Tocopherol Prevents Endothelial Dysfunction Due to Oxidized LDL by Inhibiting Protein Kinase C Stimulation
}

\author{
John F. Keaney, Jr., Yue Guo, David Cunningham, Glenn T. Shwaery, Aiming Xu, and Joseph A. Vita \\ Evans Memorial Department of Medicine and Whitaker Cardiovascular Institute, Boston University Medical Center, Boston, \\ Massachusetts 02118
}

\begin{abstract}
Excess vascular oxidative stress has been linked to impaired endothelium-dependent arterial relaxation in hypercholesterolemia. $\alpha$-Tocopherol (AT) preserves endothelial function in hypercholesterolemia although the mechanism(s) for this protective effect is (are) not known. We examined the tissue-specific effects of AT on oxidized LDL (ox-LDL)-mediated endothelial dysfunction in male New Zealand White rabbits. Animals consumed chow deficient in $(<10 \mathrm{IU} / \mathrm{kg})$ or supplemented with (1,000 IU/kg) AT for $28 \mathrm{~d}$. Exposure of thoracic aortae from AT-deficient animals to ox-LDL (0$500 \mu \mathrm{g} / \mathrm{ml}$ ) for $4 \mathrm{~h}$ produced dose-dependent inhibition of acetylcholine-mediated relaxation $(P<0.05)$ while vessels derived from animals consuming AT were resistant to oxLDL-mediated endothelial dysfunction. Animals consuming AT demonstrated a 100-fold increase in vascular AT content and this was strongly correlated with vessel resistance to endothelial dysfunction from ox-LDL $(R=0.67$; $P=0.0014)$. These results were not explained by an effect of AT on ox-LDL-mediated cytotoxicity by LDH assay or scanning electron microscopy. Vascular incorporation of AT did produce resistance to endothelial dysfunction from protein kinase $\mathrm{C}$ stimulation, an event that has been implicated in the vascular response to ox-LDL. Human aortic endothelial cells loaded with AT also demonstrated resistance to protein kinase $\mathrm{C}$ stimulation by both phorbol ester and ox-LDL. Thus, these data indicate that enrichment of vascular tissue with AT protects the vascular endothelium from ox-LDL-mediated dysfunction, at least in part, through the inhibition of protein kinase $C$ stimulation. These findings suggest one potential mechanism for the observed beneficial effect of AT in preventing the clinical expression of coronary artery disease that is distinct from the antioxidant protection of LDL. (J. Clin. Invest. 1996. 98: 386-394) Key words: endothelium • nitric oxide • vitamin E - antioxidants $\bullet$ lipoproteins
\end{abstract}

\section{Introduction}

In 1980, Furchgott and Zawadzki demonstrated the release of an endothelium-derived relaxing factor in response to acetyl-

Address correspondence to John F. Keaney, Jr., Whitaker Cardiovascular Institute, Boston University Medical Center, 80 E. Concord St., Room W507, Boston, MA 02118. Phone: 617-638-4894; FAX: 617638-4066; E-mail: jkeaney@acs.bu.edu

Received for publication 23 February 1996 and accepted in revised form 16 May 1996.

J. Clin. Invest.

(C) The American Society for Clinical Investigation, Inc.

0021-9738/96/07/0386/09 \$2.00

Volume 98, Number 2, July 1996, 386-394 choline (1). This factor has since been identified as nitric oxide $(\mathrm{NO})^{1}$ and subsequent studies have shown that NO is important in the local control of vascular tone (2) and platelet adhesion to the endothelial surface (3). Atherosclerosis (4) and hypercholesterolemia (5) are associated with abnormalities in endothelium-dependent arterial relaxation that may, in part, result from the effects of oxidized LDL (ox-LDL) on endothelium-derived NO $(6,7)$. Modified LDL inhibits receptor-mediated endothelium-dependent arterial relaxation (6) and degrades endothelium-derived NO directly (7). Moreover in atherosclerosis, ox-LDL accumulates in the vascular wall (8) where it is cytotoxic (9), and chemotactic for monocytes (10) leading to the accumulation of vascular inflammatory cells and, perhaps, the production of oxygen-derived free radicals that can inactivate endothelium-derived NO (11).

The most abundant lipid-soluble antioxidant in human plasma and LDL is $\alpha$-tocopherol (12), and the oxidation of LDL in vitro is limited by $\alpha$-tocopherol (13). Dietary supplementation with $\alpha$-tocopherol results in enhanced LDL $\alpha$-tocopherol content (14) and protection of LDL from copper- (14) and cell-mediated (13) oxidation in vitro. Plasma levels of $\alpha$-tocopherol are inversely correlated with the development of angina pectoris (15), and recent epidemiologic studies indicate that supplemental vitamin $\mathrm{E}$ consumption is inversely associated with the development of coronary artery disease in both men (16) and women (17).

The precise mechanism(s) for the beneficial effects of $\alpha$-tocopherol in coronary artery disease is (are) unclear. Since ox-LDL is implicated in the development and progression of atherosclerosis (18) and $\alpha$-tocopherol is known to limit LDL oxidation $(14,19)$, it is attractive to speculate that the beneficial effects of $\alpha$-tocopherol on coronary artery disease result from antioxidant protection of LDL. However, the effect(s) of $\alpha$-tocopherol on animal models of atherosclerosis is (are) inconsistent (20-22) despite continued protection of LDL against oxidation ex vivo (22). Clearly then, the beneficial effects of $\alpha$-tocopherol are not explained completely by its antioxidant protection of the LDL particle alone.

$\alpha$-Tocopherol is incorporated into vascular tissue $(22,23)$ and may have important physiologic effects that are not directly related to the protection of LDL against oxidation in vivo. For example, $\alpha$-tocopherol has been shown influence leukocyte adhesion to endothelial cells (24), monocyte transmigration (25), and oxidant-mediated cytotoxicity (26). Moreover, $\alpha$-tocopherol is known to inhibit protein kinase $\mathrm{C}$ in vascular smooth muscle cells (27) and protein kinase $C$ activation has been implicated in vascular disease due to diabetes (28) and ox-LDL (29). Thus, these alternative effects of $\alpha$-tocoph-

1. Abbreviations used in this paper: HAECs, human aortic endothelial cells; MDA, malondialdehyde; nLDL, native LDL; NO, nitric oxide; ox-LDL, oxidized LDL; PSS, physiologic saline solution; TBARS, thiobarbituric acid-reactive substances. 
erol have the potential to influence processes that are known to impair endothelium-dependent arterial relaxation. The purpose of this study was to examine the role of vascular $\alpha$-tocopherol content on vascular dysfunction due to ox-LDL.

\section{Methods}

Materials. Sodium pentobarbital was obtained from Anthony Products Co. (Arcadia, CA). Sodium nitroprusside was obtained from Abbot Laboratories (North Chicago, IL). Vacutainer ${ }^{\mathrm{TM}}$ tubes were purchased from Becton-Dickinson Co. (Rutherford, NJ), and Chelex 100 resin (100-200 mesh) was from Bio-Rad (Hercules, CA). Natural vitamin $\mathrm{E}(R, R, R$ - $\alpha$-tocopherol) was obtained from Henkel Co. (Kankakee, IL). The protein kinase C-specific peptide substrate, protein kinase C Ser ${ }^{25}$ (19-31), was purchased from Peninsula Laboratories (Belmont, CA). Human aortic endothelial cells (HAECs) were obtained from Clonetics (San Diego, CA). Calcium ionophore (A23187), acetylcholine hydrochloride, phenylephrine, potassium bromide $(\mathrm{KBr})$, cupric chloride $\left(\mathrm{CuCl}_{2}\right)$, Hepes, PMA, and all other compounds were purchased from Sigma Chemical Co. (St. Louis, MO).

Physiologic saline solution (PSS) contained $118.3 \mathrm{mM} \mathrm{NaCl}, 4.7$ $\mathrm{mM} \mathrm{KCl}, 2.5 \mathrm{mM} \mathrm{CaCl}_{2}, 1.2 \mathrm{mM} \mathrm{MgSO}_{4}, 1.2 \mathrm{mM} \mathrm{KH}_{2} \mathrm{PO}_{4}, 25 \mathrm{mM}$ $\mathrm{NaHCO}_{3}, 11.1 \mathrm{mM}$ glucose, $0.026 \mathrm{mM} \mathrm{Na} 2$ EDTA, and $10 \mu \mathrm{M}$ indomethacin (to inhibit prostacylin synthesis). PBS consisted of 10 $\mathrm{mM} \mathrm{NaP}, 0.15 \mathrm{M} \mathrm{NaCl}, \mathrm{pH}$ 7.4. Reagents used for LDL experiments were prepared with Chelex-treated, double-distilled, deionized water in order to prevent premature LDL oxidation catalyzed by trace amounts of transition metal ions. A23187 and PMA were prepared and diluted in DMSO.

LDL isolation and oxidation. Plasma was collected from a group of five normolipemic volunteers into heparin-loaded Vacutainer ${ }^{\mathrm{TM}}$ tubes and LDL isolated as described by Chung and colleagues (30). Isolated LDL was then subjected to size exclusion chromatography using Sephadex G-25M PD-10 columns (Pharmacia, Uppsala, Sweden) equilibrated with PSS to remove potassium bromide, ascorbate, and urate (23). LDL prepared in this manner was designated native LDL (nLDL). Ox-LDL was prepared exactly as nLDL except size exclusion chromatography was performed in Sephadex G-25M equilibrated with glucose- and EDTA-free PSS followed by incubation with $10 \mu \mathrm{M} \mathrm{CuCl}_{2}$ at $37^{\circ} \mathrm{C}$ for $24 \mathrm{~h}$. Copper was then removed from ox-LDL by gel-filtration with Sephadex G-25M equilibrated with PSS. Both nLDL and ox-LDL were stored at $4^{\circ} \mathrm{C}$ under $\mathrm{N}_{2}$ for no longer than 1 wk. LDL protein content was determined by the method of Lowry (31) using bovine serum albumin as a standard. Indomethacin was omitted from PSS used for LDL isolation and oxidation.

LDL oxidation was quantified by the LDL content of thiobarbituric acid-reactive substances (TBARS) and relative electrophoretic mobility by agarose gel electrophoresis (32). For TBARS determination, an aliquot of LDL ( $0.1 \mathrm{mg}$ LDL protein in $0.5 \mathrm{ml} \mathrm{PBS})$ was incubated with equal volumes of $2.8 \%(\mathrm{wt} / \mathrm{vol})$ trichloroacetic acid and $1 \%(\mathrm{wt} / \mathrm{vol}$ ) thiobarbituric acid (in $50 \mathrm{mM} \mathrm{NaOH}$ ) for $10 \mathrm{~min}$ at $100^{\circ} \mathrm{C}$, extracted with $2.0 \mathrm{ml} n$-butanol, and the extract absorbance determined at $532 \mathrm{~nm}$. TBARS were determined from a standard curve prepared with 1,1,3,3-tetramethoxypropane. TBARS are expressed as nanomoles of malondialdehyde (MDA) equivalents per milligram of LDL protein.

Animal subjects. Male New Zealand White rabbits $(2.5-3.5 \mathrm{~kg})$ were used for this study. Animals consumed food and water ad libitum. Commercial rabbit chow contains substantial amounts of $\alpha$-tocopherol, and in preliminary experiments we were only able to achieve a modest increase in plasma $\alpha$-tocopherol with the addition of $1,000 \mathrm{IU} \alpha$-tocopherol $/ \mathrm{kg}$ chow. To produce a more substantial difference in plasma $\alpha$-tocopherol between treatment groups, we developed a synthetic $\alpha$-tocopherol-deficient diet (Research Diets Inc., New Brunswick, NJ) containing $<10 \mathrm{IU} / \mathrm{kg}$ total tocopherols. The
Table I. Composition of Purified Rabbit Diet

\begin{tabular}{lc}
\hline \multicolumn{1}{c}{ Ingredient } & Quantity \\
\hline & grams/kg chow \\
Soy protein & 200 \\
D,L-Methionine & 3 \\
Cornstarch & 200 \\
Sucrose & 325 \\
Cellulose & 125 \\
Guar gum & 25 \\
Canola oil & 20 \\
Coconut oil & 30 \\
Salt mix & 60 \\
Vitamin mix (without vitamin E) & 10 \\
Choline bitartrate & 2 \\
Total & 1000 \\
\end{tabular}

The salt mix (60 grams) contained: calcium carbonate, 8.0 grams; calcium phosphate, 4.0 grams; magnesium oxide, 0.5 grams; potassium citrate, 10.0 grams; potassium sulfate, 0.25 grams; sodium chloride, 2.0 grams; chromium potassium sulfate, $0.2 \mathrm{mg}$; cupric carbonate, $0.6 \mathrm{mg}$; potassium iodide, $0.2 \mathrm{mg}$; ferric citrate 0.1 grams; manganous carbonate, $50 \mathrm{mg}$; sodium selenite, $0.2 \mathrm{mg}$; zinc carbonate, $50 \mathrm{mg}$. The vitamin mix (10 grams) contained: 5,000 IU vitamin A palmitate; 1,000 IU vitamin $\mathrm{D}_{3} ; 2.0 \mathrm{mg}$ menadione; $0.2 \mathrm{mg}$ biotin; $10 \mu \mathrm{g}$ cyanocobalilamin; $2 \mathrm{mg}$ folic acid; $20 \mathrm{mg}$ nicotinic acid; $10 \mathrm{mg}$ pyridoxine; $5 \mathrm{mg}$ riboflavin; and $5 \mathrm{mg}$ thiamine.

composition of this diet is contained in Table I. The $\alpha$-tocopherolsupplemented diet was identical in composition to the tocopheroldeficient diet except for the addition of $1,000 \mathrm{IU} / \mathrm{kg} R, R, R$ - $\alpha$-tocopherol (Henkel Co.). All animal studies were approved by the Boston University Medical Center Institutional Animal Care and Use Committee.

In vitro assay of vascular function. The thoracic aorta was isolated from New Zealand White rabbits killed with pentobarbital (120 $\mathrm{mg} / \mathrm{kg}$ ) via a marginal ear vein. Vessel segments were prepared, suspended in organ chambers as described previously (23), and gassed with $15 \% \mathrm{O}_{2} / 5 \% \mathrm{CO}_{2} / 80 \% \mathrm{~N}_{2}$ to produce physiologic oxygen tension $\left(\mathrm{PO}_{2} \sim 100\right.$ Torr $)$. After equilibration for $90 \mathrm{~min}$, vessels were contracted with phenylephrine $(1 \mu \mathrm{M})$ and endothelial control of vascular tone was assayed by the addition of acetylcholine (final concentration $1 \mathrm{nM}$ to $10 \mu \mathrm{M})$. Vessels were then washed extensively, followed by incubation with nLDL $(500 \mu \mathrm{g} / \mathrm{ml} \times 4 \mathrm{~h})$ or ox-LDL $(100-500 \mu \mathrm{g} /$ $\mathrm{ml} \times 4 \mathrm{~h})$ or ox-LDL $(100-500 \mu \mathrm{g} / \mathrm{ml} \times 4 \mathrm{~h})$. After incubation, vessels were washed three times with PSS and relaxation was examined in response to acetylcholine as above. In certain experiments, PMA was added to organ chambers containing freshly prepared vessels 15 min prior to assessment of vascular function. The responses to calcium ionophore $\mathrm{A} 23187(0.3 \mathrm{nM}$ to $1 \mu \mathrm{M})$ or nitroglycerin $(1 \mathrm{nM}$ to 10 $\mu \mathrm{M})$ were examined in vessels only after exposure to the above agents with buffer-exposed vessels serving as a control. In selected experiments, vascular function studies were performed with PSS containing $\alpha$-tocopherol at a final concentration of $100 \mu \mathrm{M}$. In these incubations, the final ethanol concentration was $0.1 \%$ and control incubations contained an identical amount of ethanol.

Plasma and aortic $\alpha$-tocopherol content. Plasma $\alpha$-tocopherol content was determined with reverse-phase HPLC and electrochemical detection as described (33). For aortic $\alpha$-tocopherol content, tissue samples (0.1-0.35 grams) were prepared as described (23) and subjected to reverse-phase HPLC as above. Calibration of the HPLC system was performed daily using fresh solutions of $R, R, R$ - $\alpha$-tocopherol in ethanol. 
Vascular LDH release and scanning electron microscopy. Segments of thoracic aorta $(2.5 \mathrm{~cm})$ were harvested as above, incubated in PSS $(1 \mathrm{ml})$ or PSS containing $500 \mu \mathrm{g} / \mathrm{ml} \mathrm{nLDL}$ or $500 \mu \mathrm{g} / \mathrm{ml} \mathrm{ox-}$ LDL. Samples were continuously bubbled with $15 \% \quad \mathrm{O}_{2} / 5 \% \quad \mathrm{CO}_{2} /$ $80 \% \mathrm{~N}_{2}$, and after $4 \mathrm{~h}$ the buffer LDH content was determined using a commercially available kit (LDH1, Sigma Chemical Co.). After incubation, vessels were homogenized in $1 \mathrm{ml}$ of PSS and the LDH content of the buffer was determined as a positive control. Authentic LDH standards (Sigma Chemical Co.) processed in the same manner demonstrated that nLDL and ox-LDL did not interfere with the LDH assay. Identically processed vessels were then fixed and subjected to scanning electron microscopy as described (22).

Cell culture. HAEC cultures were maintained in medium EGM (Clonetics) containing $5 \mu \mathrm{g} / \mathrm{ml}$ endothelial cell growth factor, $2 \%$ fetal bovine serum, gentamicin $(50 \mu \mathrm{g} / \mathrm{ml})$, amphotericin B $(100 \mathrm{ng} / \mathrm{ml})$, and $1 \mu \mathrm{g} / \mathrm{ml}$ hydrocortisone. Cells were grown in T25 flasks coated with gelatin and passaged using calcium and magnesium-free HBSS and trypsin-EDTA. Endothelial cells were characterized by phasecontrast cellular morphology, the presence of von Willebrand factor antigen, and their ability to endocytose acetylated LDL.

Measurement of protein kinase C activity. Protein kinase $\mathrm{C}$ activity was measured in situ using the method of Williams and Schrier (34) modified for endothelial cells. Before the study of protein kinase C stimulation, cells were plated in 96-well plates (Costar Corp., Cambridge, MA) and allowed to reach confluence over 4-7 d. To determine the effect of cellular $\alpha$-tocopherol status on protein kinase $\mathrm{C}$ stimulation, HAECs were treated with $\alpha$-tocopherol $(100 \mu \mathrm{M})$ or vehicle $(0.1 \%$ ethanol) for $72 \mathrm{~h}$ prior to reaching confluency. This treatment had no effect on cell growth as total cell protein in the tocopherol- and vehicle-treated cells grown in 6-well plates was the same $(0.79 \pm 0.26$ vs. $0.76 \pm 0.41 \mathrm{mg} /$ well, respectively; $P=0.57)$. To remove unincorporated $\alpha$-tocopherol, HAEC were washed three times with HBSS and protein kinase $C$ stimulation was assessed in response to a 15-min treatment with PMA (in 0.1\% DMSO) or a 4-h treatment with either nLDL $(300 \mathrm{mg} / \mathrm{ml}$ protein) or ox-LDL $(300 \mu \mathrm{g} / \mathrm{ml}$ protein). The assay buffer $(40 \mu \mathrm{l})$ contained $137 \mathrm{mM} \mathrm{NaCl}, 5.4 \mathrm{mM} \mathrm{KCl}$, $10 \mathrm{mM} \mathrm{MgCl}_{2}, 0.3 \mathrm{mM} \mathrm{NaH}_{2} \mathrm{PO}_{4}, 0.4 \mathrm{mM} \mathrm{KH}_{2} \mathrm{PO}_{4}, 25 \mathrm{mM} \beta$-glycerophosphate, $5.5 \mathrm{mM}$ D-glucose, $5 \mathrm{mM}$ EGTA, $1 \mathrm{mM} \mathrm{CaCl}_{2}, 1 \mu \mathrm{Ci}[\gamma$ $\left.{ }^{32} \mathrm{P}\right] \mathrm{ATP}$ (6,000 Ci/mmol; New England Nuclear, Boston, MA), $50 \mu \mathrm{g} /$ $\mathrm{ml}$ digitonin, $20 \mathrm{mM}$ Hepes ( $\mathrm{pH}$ 7.2), and $100 \mu \mathrm{M} \mathrm{Ser}{ }^{25}$ protein kinase $\mathrm{C}$ specific substrate. The kinase reaction was terminated by the addition of $10 \mu \mathrm{l} 25 \%$ (wt/vol) trichloroacetic acid, an aliquot (45 $\mu \mathrm{l})$ spotted onto Whatman P-81 paper, and the paper washed three times with $75 \mathrm{mM}$ phosphoric acid. The protein kinase $\mathrm{C}$-dependent phosphorylation of the peptide substrate was derived by scintillation counting. In all assays, a parallel assay without protein kinase $\mathrm{C}$ substrate was subtracted to account for nonspecific kinase activity.

Data analysis. Unless otherwise specified, all values are presented as a mean \pm standard error. The vascular responses to the agents acetylcholine, A23187, and nitroglycerin are reported as the percent relaxation compared with the contraction produced by $1 \mu \mathrm{M}$ phenylephrine. The dose responses to acetylcholine, A23187, and sodium nitroprusside were compared within groups using repeatedmeasures ANOVA. Vascular responses were compared between dietary groups with two-way ANOVA. LDH and protein kinase $\mathrm{C}$ activity were compared among treatments using repeated-measures ANOVA or Friedman's repeated measures on ranks as appropriate. Statistically significant differences with ANOVA were further examined using a post-hoc Neuman-Keuls or Dunnet's test where appropriate. Statistical significance was accepted if the null hypothesis was rejected at the $P<0.05$ level.

\section{Results}

Characteristics of $n L D L$ and $o x-L D L$. NLDL isolated from this study was characterized by TBARS of $0.01 \pm 0.01 \mathrm{nmol}$ $\mathrm{MDA} / \mathrm{mg}$ LDL protein ( $n=4 \mathrm{LDL}$ preparations). In contrast,
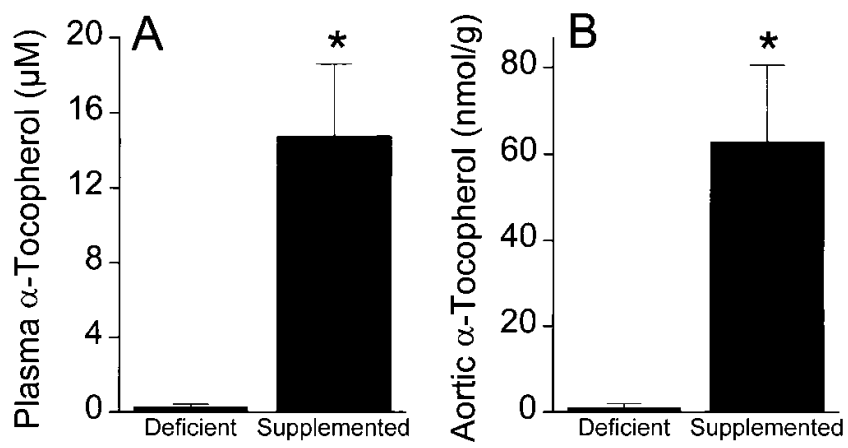

Figure 1. Plasma and aortic $\alpha$-tocopherol content in study animals. Samples of plasma and thoracic aorta were harvested from animals consuming diets that were deficient in $(<10 \mathrm{IU}$ total tocopherols $/ \mathrm{kg})$ or supplemented with $(1,000 \mathrm{IU} / \mathrm{kg}) \alpha$-tocopherol for $28 \mathrm{~d}$. The plasma $(A)$ and aortic $(B) \alpha$-tocopherol content were determined using reverse-phase HPLC with electrochemical detection as described in Methods. Data are displayed as mean \pm SEM and are derived from seven animals in each group; ${ }^{*} P<0.001$ vs. $\alpha$-tocopherol-deficient animals.

ox-LDL prepared for this study demonstrated a TBARS content of $38.2 \pm 5.8 \mathrm{nmol} \mathrm{MDA} / \mathrm{mg}$ LDL protein $(P<0.001 \mathrm{vs}$. nLDL, $n=4)$ and a relative electrophoretic mobility of $4.2 \pm 0.9$ compared with nLDL $(n=4)$.

Plasma and aortic $\alpha$-tocopherol content. The plasma and aortic $\alpha$-tocopherol content reflected dietary treatment and is contained in Fig. 1. Animals consuming the $\alpha$-tocopherol-deficient diet were characterized by a plasma $\alpha$-tocopherol concentration of $0.29 \pm 0.13 \mu \mathrm{M}$ and an aortic $\alpha$-tocopherol content of $0.42 \pm 0.13 \mathrm{nmol} / \mathrm{gram}$. In contrast, animals consuming the $\alpha$-tocopherol-supplemented diet demonstrated plasma and aortic $\alpha$-tocopherol levels of $14.4 \pm 3.8 \mu \mathrm{M}$ and $62.9 \pm 17.6$ nmol/gram, respectively (both $P<0.002$ vs. $\alpha$-tocopheroldeficient animals).

ox-LDL and endothelium-dependent relaxation. Thoracic aorta from $\alpha$-tocopherol-deficient animals incubated in PSS containing $\mathrm{nLDL}(500 \mu \mathrm{g} / \mathrm{ml})$ for $4 \mathrm{~h}$ demonstrated dosedependent relaxation to acetylcholine with a maximal relaxation of $73 \pm 4 \%$ (Fig. $2 A$ ) and this was not significantly different from vessels incubated with PSS alone (data not shown). In contrast, a 4-h incubation of arterial segments from these animals with ox-LDL inhibited acetylcholine-mediated arterial relaxation in a dose-dependent manner (Fig. $2 A$ ). Arteries incubated with 100,300 , or $500 \mu \mathrm{g} / \mathrm{ml}$ ox-LDL for $4 \mathrm{~h}$ demonstrated a maximal relaxation to $10 \mu \mathrm{M}$ acetylcholine of $63 \pm$ $6 \%, 48 \pm 7 \%$, and $45 \pm 6 \%$, respectively ( $P<0.05$ for 300 and $500 \mu \mathrm{g} / \mathrm{ml}$ ox-LDL vs nLDL by ANOVA and Dunnet's). Vessels derived from animals consuming the $\alpha$-tocopherol-supplemented diet did not demonstrate any inhibition of endothelium-dependent arterial relaxation to acetylcholine in response to ox-LDL (Fig. $2 B$ ).

The dose-dependent effects of ox-LDL on endotheliumdependent arterial relaxation to acetylcholine are summarized graphically in Fig. $3 \mathrm{~A}$. In animals consuming the $\alpha$-tocopherol-deficient diet, incubation of arteries with 100, 300, and $500 \mu \mathrm{g} / \mathrm{ml}$ ox-LDL significantly reduced acetylcholine-mediated arterial relaxation to $82 \pm 8 \%, 51 \pm 10 \%$, and $44 \pm 8 \%$ of the preincubation value, respectively $(P<0.001$ for trend by repeated-measures ANOVA). In contrast, incubation of vessels derived from animals consuming the $\alpha$-tocopherol-supple- 


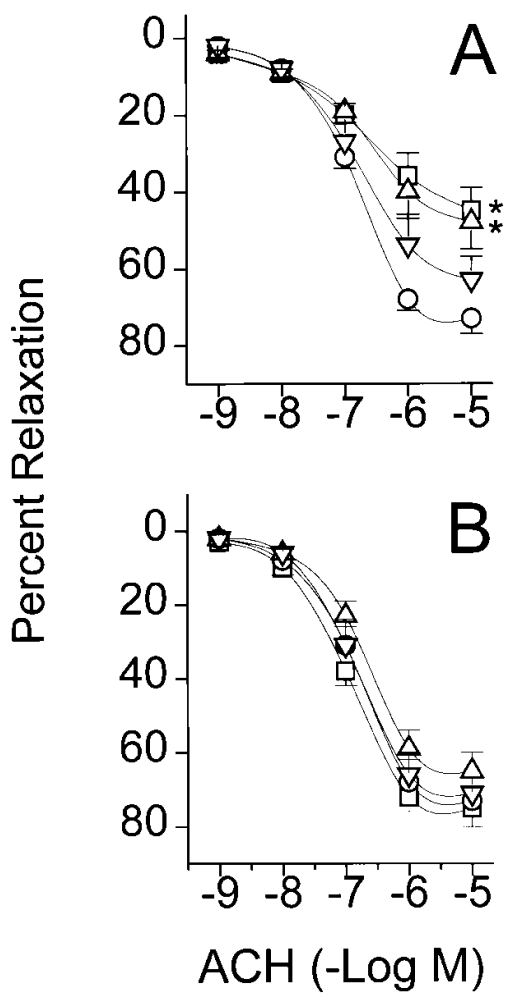

Figure 2. The effect of ox-LDL on endothelium-dependent arterial relaxation to acetylcholine. The thoracic aorta was harvested from New Zealand White rabbits fed an $\alpha$-tocopherol-deficient (A) or $\alpha$-tocopherolsupplemented diet $(B)$ for a period of $4 \mathrm{wk}$. Vessels were prepared and suspended in organ chambers as described in Methods and incubated in PSS containing $\mathrm{nLDL}(500 \mu \mathrm{g} / \mathrm{ml}, \bigcirc)$, or ox-LDL at protein concentrations of 100 $\mu \mathrm{g} / \mathrm{ml}(\nabla), 300 \mu \mathrm{g} / \mathrm{ml}$ $(\triangle)$, or $500 \mu \mathrm{g} / \mathrm{ml}(\square)$. After incubation for $4 \mathrm{~h}$, vessels were washed three times with PSS, contracted with $1 \mu \mathrm{M}$ phenylephrine, and exposed to the indicated concentrations of ace-

tylcholine. Data are mean \pm SEM and are derived from five to seven animals in each group. $* P<0.05$ vs. nLDL by two-way ANOVA.

mented diet with ox-LDL did not significantly impair arterial relaxation to acetylcholine (Fig. $3 \mathrm{~A}$ ). Moreover, vascular $\alpha$-tocopherol content correlated with arterial relaxation to 1 $\mu \mathrm{M}$ acetylcholine after exposure to ox-LDL $(\mathrm{R}=0.67 ; P=$ $0.0014)$. The arterial responses to nitroglycerin, a direct NOdependent vasodilator, were not impaired by exposure to oxLDL and the responses in $\alpha$-tocopherol-deficient and $\alpha$-tocopherol-supplemented animals were similar (Fig. 3 B). The responses to A23187, a receptor-independent agonist of endothelial NO synthesis, were not impaired in response to oxLDL in either $\alpha$-tocopherol-deficient or $\alpha$-tocopherol-supplemented animals (data not shown).

We next assessed the requirement for tissue incorporation of $\alpha$-tocopherol as a means of protection against ox-LDLmediated endothelial dysfunction. Segments of thoracic aorta from animals consuming an $\alpha$-tocopherol-deficient diet were incubated with ox-LDL for $4 \mathrm{~h}$ in the presence or absence of added $\alpha$-tocopherol $(100 \mu \mathrm{M})$ and these results are presented in Fig. 4. This concentration of $\alpha$-tocopherol represents the upper limit of plasma concentrations in patients receiving $\alpha$-tocopherol supplementation (35). As above, incubation of arterial rings with ox-LDL (100-500 $\mu \mathrm{g} / \mathrm{ml})$ was associated with a significant dose-dependent inhibition of acetylcholinemediated arterial relaxation $(P<0.001$ for trend by repeatedmeasures ANOVA). The presence of $\alpha$-tocopherol in the incubation did not significantly inhibit endothelial dysfunction due to ox-LDL (Fig. 4).

Arterial $\alpha$-tocopherol content and cytotoxicity from ox- $L D L$. Oxidized LDL is cytotoxic to cells in culture and $\alpha$-tocopherol is known to inhibit this cytotoxicity (36). Therefore, we sought to determine if the known effects of $\alpha$-tocopherol on ox-LDLmediated cytotoxicity were responsible for the results reported

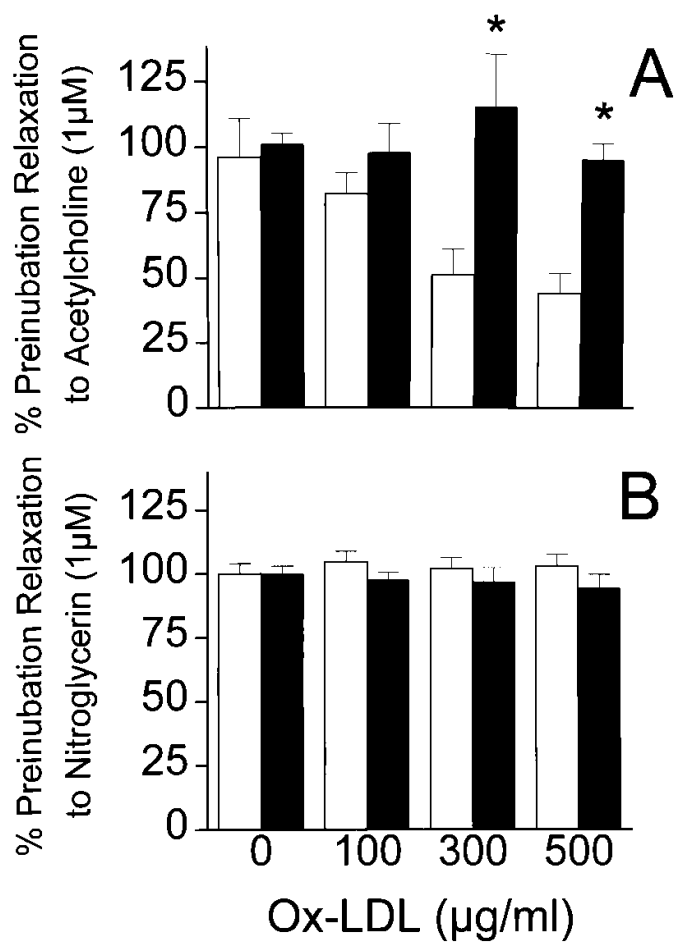

Figure 3. The effect of vascular $\alpha$-tocopherol content on ox-LDLmediated endothelial dysfunction. Segments of thoracic aorta were harvested from New Zealand White rabbits fed either an $\alpha$-tocopherol-deficient (open bars) or an $\alpha$-tocopherol-supplemented diet (closed bars) for a period of $4 \mathrm{wk}$. Vessels were suspended in organ chambers, contracted with $1 \mu \mathrm{M}$ phenylephrine, and relaxation tested in response to acetylcholine $(1 \mu \mathrm{M})$ or nitroglycerin $(1 \mu \mathrm{M})$. Vessels were washed, incubated with the indicated concentrations of ox-LDL for $4 \mathrm{~h}$, washed three times, and relaxation to acetylcholine or nitroglycerin repeated. Results represent the relaxation to acetylcholine $(A)$ or nitroglycerin $(B)$ after incubation with ox-LDL expressed as a percentage of the preincubation relaxation at the same dose. Data are mean \pm SEM and are derived from 5-10 animals in each dietary group. $* P<0.05$ vs. response in $\alpha$-tocopherol-supplemented animals.

here. We incubated vessel segments from our study animals in PSS alone or PSS containing $500 \mu \mathrm{g} / \mathrm{ml} \mathrm{nLDL}$ or $500 \mu \mathrm{g} / \mathrm{ml}$ oxLDL for $4 \mathrm{~h}$ and examined LDH release from these vessels as an index of cytotoxicity. Incubation of vessels from $\alpha$-tocopherol-deficient and-supplemented animals with PSS alone resulted in minimal LDH release into the incubation buffer (Table II). Incubation of vessels from both treatment groups with either nLDL or ox-LDL resulted in similar degrees of LDH release. Most importantly, there was no difference in the extent of $\mathrm{LDH}$ release in response to ox-LDL based upon $\alpha$-tocopherol status (Table II). Homogenization of vessels from both treatment groups as a positive control produced a 40 -fold increase in LDH release that was highly significant (Table II).

Because LDH release is a late phenomenon in cell dysfunction/death, we used scanning electron microscopy to examine endothelial cell morphology in response to the incubation conditions used here. Fig. 5, $A-D$, contains representative scanning electron micrographs from vessels incubated as in Table II. Incubation of thoracic aorta with nLDL or ox-LDL for $4 \mathrm{~h}$ was associated with endothelial cell morphology that was similar to normal aorta. Thus, the incubation conditions used in 


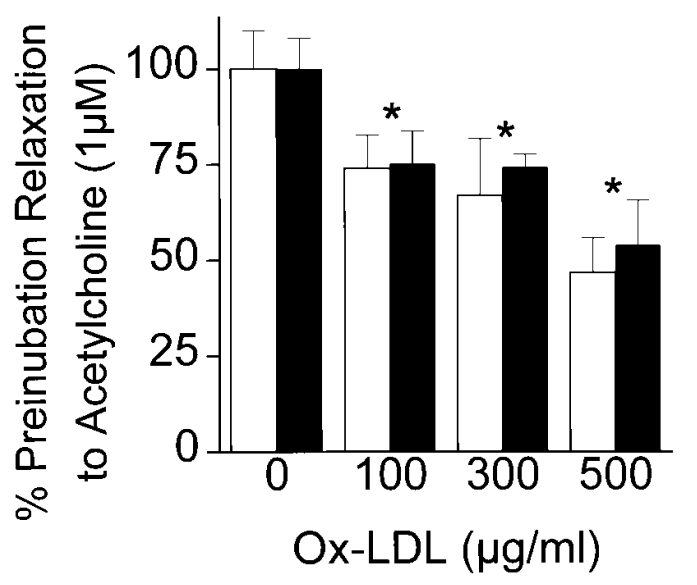

Figure 4. Acute $\alpha$-tocopherol exposure and ox-LDL-mediated endothelial dysfunction. Segments of thoracic aorta were harvested from New Zealand White rabbits fed an $\alpha$-tocopherol-deficient diet. Vessels were suspended in organ chambers, contracted with $1 \mu \mathrm{M}$ phenylephrine, and relaxation tested in response to acetylcholine (1 $\mathrm{nM}$ to $10 \mu \mathrm{M})$. Vessels were washed, incubated with the indicated concentrations of ox-LDL for $4 \mathrm{~h}$ in PSS alone (open bars) or PSS containing $100 \mu \mathrm{M} \alpha$-tocopherol (closed bars), washed three times, and relaxation to acetylcholine repeated. Results represent the relaxation to $1 \mu \mathrm{M}$ acetylcholine after incubation with ox-LDL expressed as a percent of the preincubation acetylcholine relaxation at the same dose. Data are mean \pm SEM and are derived from seven animals. $* P<0.05$ vs. $0 \mu \mathrm{g} / \mathrm{ml}$ ox-LDL by repeated-measures ANOVA.

this study were not associated with significant endothelial cell toxicity as assessed by $\mathrm{LDH}$ release and scanning electron microscopy.

$\alpha$-Tocopherol and impaired endothelium-dependent arterial relaxation due to protein kinase $C$. Protein kinase $\mathrm{C}$ acti-
Table II. LDH Release in Thoracic Vessel Incubations

\begin{tabular}{lcc}
\hline & \multicolumn{2}{c}{ Experimental group } \\
\cline { 2 - 3 } \multicolumn{1}{c}{ Incubation condition } & $\alpha$-Tocopherol-deficient & $\alpha$-Tocopherol-supplemented \\
\hline PSS alone & $2.5 \pm 1.1$ & $1.9 \pm 1.1$ \\
PSS + nLDL $(500 \mu \mathrm{g} / \mathrm{ml})$ & $12.2 \pm 1.4$ & $11.1 \pm 3.9$ \\
$\quad+$ ox-LDL $(500 \mu \mathrm{g} / \mathrm{ml})$ & $12.8 \pm 5.7$ & $14.3 \pm 3.4$ \\
Vessel homogenate & $86.9 \pm 2.4^{*}$ & $87.5 \pm 6.5^{*}$ \\
& & \\
\end{tabular}

Segments of thoracic aorta $(2.5 \mathrm{~cm})$ were harvested as above, incubated in PSS ( $1 \mathrm{ml})$ or PSS containing nLDL or ox-LDL. Samples were continuously bubbled with $15 \% \mathrm{O}_{2} / 5 \% \mathrm{CO}_{2} / 80 \% \mathrm{~N}_{2}$ and after $4 \mathrm{~h}$, the buffer LDH content (U/liter) was determined using a commercially available kit (LDH1; Sigma). After incubation, vessels were homogenized in the remaining PSS and the LDH content determined as a positive control. Data represent mean \pm SEM derived from five to seven experiments. $* P<0.05$ vs. PSS alone by repeated-measures ANOVA.

vation has been implicated in endothelial dysfunction due to ox-LDL (29) and $\alpha$-tocopherol is known to inhibit protein kinase $\mathrm{C}(37,38)$. To investigate protein kinase $\mathrm{C}$ inhibition as a mechanism for the beneficial effect of $\alpha$-tocopherol, we examined the effect of $50 \mathrm{nM}$ PMA, a potent stimulant of protein $\mathrm{ki}$ nase $\mathrm{C}$, on vascular relaxation to acetylcholine, A23187, and nitroglycerin and these results are shown in Fig. 6. With vehicle control, arterial relaxation to acetylcholine was similar in the $\alpha$-tocopherol-supplemented and -deficient animals (Fig. 6 $A)$. Incubation of vessels derived from the $\alpha$-tocopherol-deficient animals with PMA resulted in impaired arterial relaxation to acetylcholine ( $P<0.05$ vs. without PMA). In contrast, arterial relaxation to acetylcholine was not significantly impaired by PMA in vessels derived from the $\alpha$-tocopherol-sup-
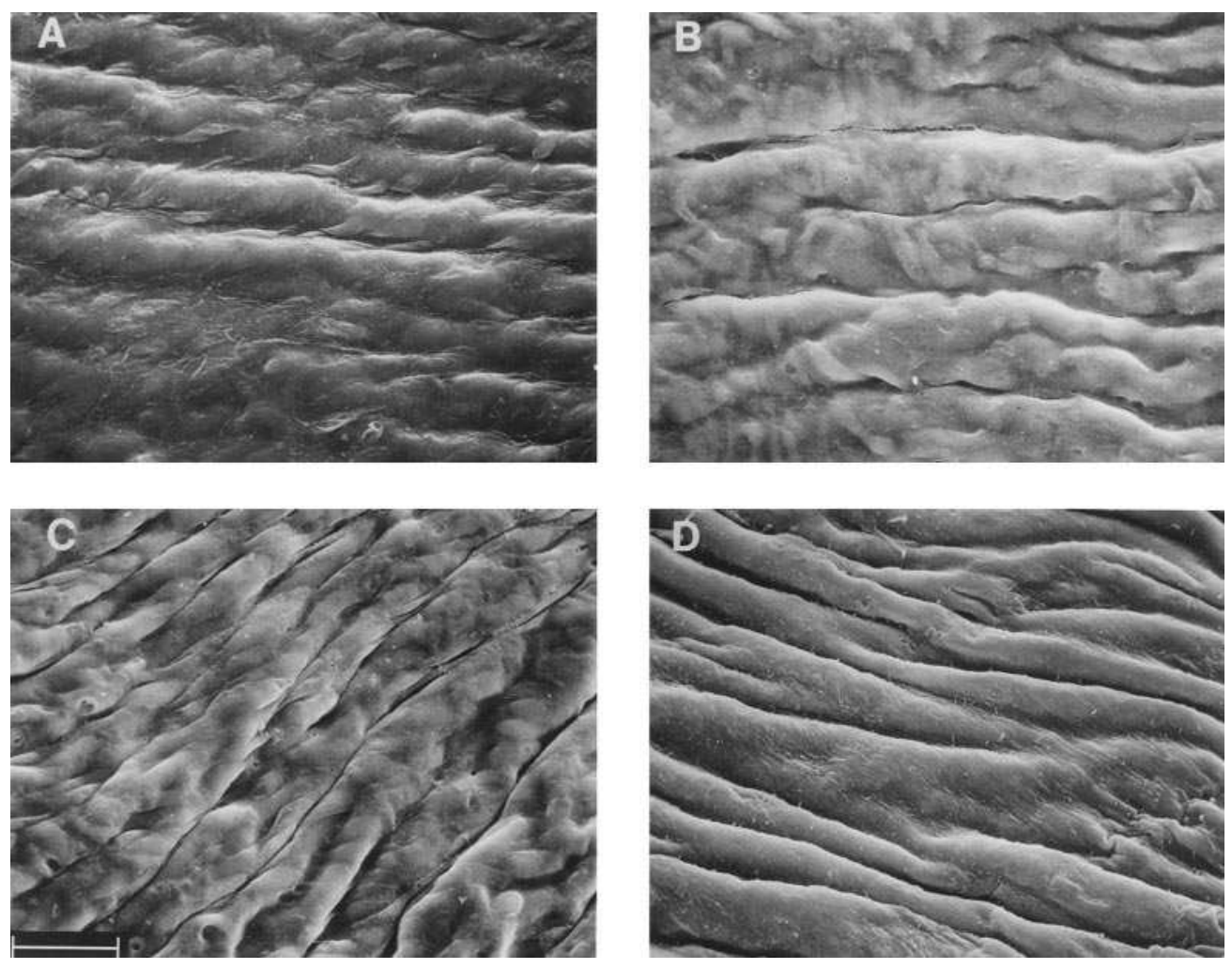

Figure 5. Representative scanning electron micrographs demonstrating endothelial cell morphology after a 4-h exposure to nLDL and ox-LDL in study animals. $(A)$ normal thoracic aorta from an $\alpha$-tocopherol-deficient animal; $(B)$ thoracic aorta from an $\alpha$-tocopherol-deficient animal incubated with nLDL (500 $\mu \mathrm{g} / \mathrm{ml}) ;(C)$ thoracic aorta from an $\alpha$-tocopherol-deficient animal incubated with ox-LDL (500 $\mu \mathrm{g} / \mathrm{ml})$ and; $(D)$ thoracic aorta from an $\alpha$-tocopherol-supplemented animal incubated with $500 \mu \mathrm{g} / \mathrm{ml}$ ox-LDL. Bar at lower left represents the scale reference of $30 \mu \mathrm{m}$. 


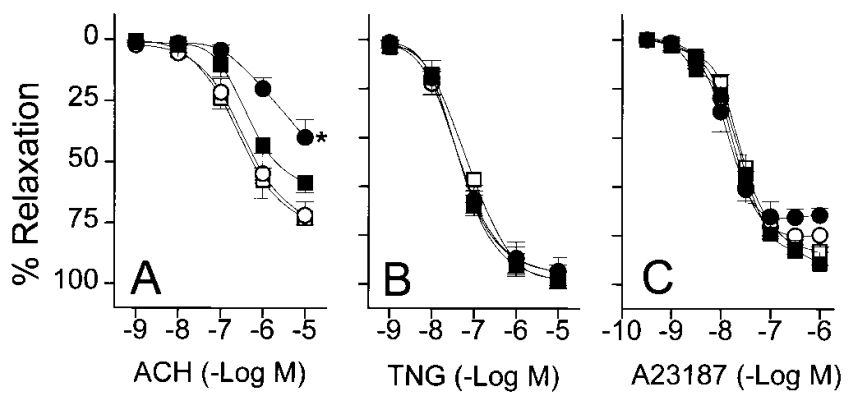

Figure 6. The effect of vascular $\alpha$-tocopherol content on PMA-mediated endothelial dysfunction. Vessels were harvested from New Zealand White rabbits fed an $\alpha$-tocopherol-deficient (circles) or an $\alpha$-tocopherol-supplemented diet (squares) for a period of $4 \mathrm{wk}$. Harvested vessels were incubated with PSS alone (open symbols) or PSS containing $50 \mathrm{nM}$ PMA (closed symbols) for $10 \mathrm{~min}$. After incubation, vessels were contracted with $1 \mu \mathrm{M}$ phenylephrine and relaxation was recorded in response to the indicated dose of acetylcholine $(A C H)$, nitroglycerin $(T N G)$, or A23187. Data are mean \pm SEM and are derived from seven animals in each group. $* P<0.05$ vs. PSS alone by two-way ANOVA.

plemented animals ( $P=0.48$ by ANOVA; Fig. $6 A$ ). Arterial relaxation to $\mathrm{A} 23187$ or nitroglycerin was not materially affected by PMA (Fig. 6, $B$ and $C$ ). Thus, vessels derived from animals supplemented with $\alpha$-tocopherol are resistant to protein kinase $\mathrm{C}$-mediated endothelial dysfunction.

$H A E C \alpha$-tocopherol content and protein kinase $C$ stimulation. Having established that vascular incorporation of $\alpha$-tocopherol prevents endothelial dysfunction by both ox-LDL and protein kinase $\mathrm{C}$ stimulation, we next sought to determine if $\alpha$-tocopherol limits protein kinase $\mathrm{C}$ stimulation in endothelial cells. Compared with vehicle $(0.1 \%$ ethanol), incubation of HAECs with $100 \mu \mathrm{M} \alpha$-tocopherol for $72 \mathrm{~h}$ increased cellular $\alpha$-tocopherol content from undetectable levels $(<0.001 \mathrm{pmol} /$ $\mu \mathrm{g}$ cell protein) to $0.69 \pm 0.23 \mathrm{pmol} / \mu \mathrm{g}$ cell protein $(N=3 ; P<$ $0.001)$. This increase in HAEC $\alpha$-tocopherol content was associated with a significant reduction in protein kinase $\mathrm{C}$ activity to $35 \pm 20 \%$ of that observed in vehicle-treated cells $(P<0.05$ vs. vehicle treatment; Fig. 7). In fact, the reduction in protein kinase $\mathrm{C}$ activity in $\alpha$-tocopherol-loaded cells was comparable with that observed with protein kinase $\mathrm{C}$ downregulation using a $24-h$ treatment with $1 \mu$ M PMA $(36 \pm 20 \%$ vs. $48 \pm 14 \%$, respectively; $P=\mathrm{NS}$ ). This effect of $\alpha$-tocopherol on HAEC protein kinase $C$ activity was also evident with PMA stimulation. $\alpha$-Tocopherol-loaded HAECs demonstrated only $75 \%$ of the protein kinase $\mathrm{C}$ activity in response to PMA stimulation compared with cells that were not loaded with $\alpha$-tocopherol (108土 $6 \%$ of control vs. $145 \pm 11 \%$ of control, respectively; Fig. 7 ).

To determine the effect of ox-LDL on HAEC protein kinase $\mathrm{C}$ activity, we loaded HAECs with $\alpha$-tocopherol or vehicle as above and incubated these cells with $300 \mu \mathrm{g} / \mathrm{ml}$ ox-LDL or nLDL. In vehicle-treated cells ox-LDL produced an increase in endothelial cell protein kinase $C$ activity of $67 \pm 26 \%$ $(P<0.05)$ while nLDL had no effect on HAEC protein kinase $\mathrm{C}$ activity (Fig. 8). The increase in protein kinase $\mathrm{C}$ activity due to ox-LDL was prevented in HAECs loaded with $\alpha$-tocopherol (Fig. 8). Thus, endothelial cell incorporation of $\alpha$-tocopherol inhibits basal protein kinase $\mathrm{C}$ activity and stimulation of protein kinase $\mathrm{C}$ with either PMA or ox-LDL.

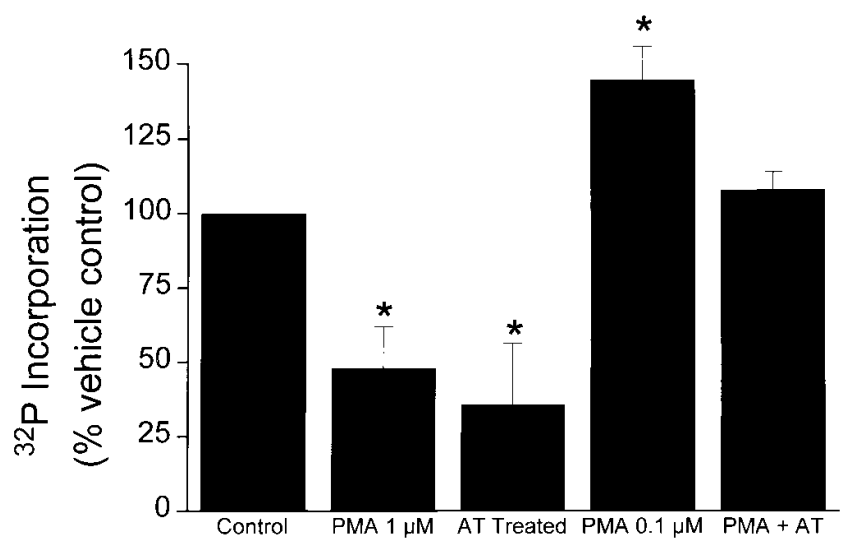

Figure 7. The effect of HAEC $\alpha$-tocopherol content on protein kinase $\mathrm{C}$ activity. Monolayers of HAECs were loaded with $\alpha$-tocopherol $(100 \mu \mathrm{M})$ or vehicle for $3 \mathrm{~d}$, washed, and treated with PMA (100 $\mathrm{nM}$ for $15 \mathrm{~min}$ ) or vehicle ( $0.1 \% \mathrm{DMSO})$ prior to the assessment of protein kinase $\mathrm{C}$ activity as described in Methods. Downregulation of protein kinase $\mathrm{C}$ activity was achieved by treating cells with $1 \mu \mathrm{M}$ PMA for $24 \mathrm{~h}$ prior to assessment of protein kinase C activity. Results represent the mean \pm SEM of three independent experiments, ${ }^{*} P<$ 0.05 vs. control.

\section{Discussion}

The data presented here indicate that $\alpha$-tocopherol prevents arterial dysfunction due to ox-LDL purely as a function of the tissue content of $\alpha$-tocopherol. Using dietary treatment, we manipulated the $\alpha$-tocopherol content of arterial tissue and demonstrated that $\alpha$-tocopherol prevented endothelial vasodilator dysfunction due to ox-LDL. Moreover, the protective effect of $\alpha$-tocopherol against ox-LDL-mediated endothelial dysfunction was directly related to the vascular content of $\alpha$-tocopherol and was not a consequence of cytotoxicity due to ox-LDL. The beneficial effect of $\alpha$-tocopherol was strictly dependent upon its tissue incorporation as coincubation of vessels from $\alpha$-tocopherol-deficient animals with $\alpha$-tocopherol had no effect against ox-LDL-mediated endothelial dysfunc-

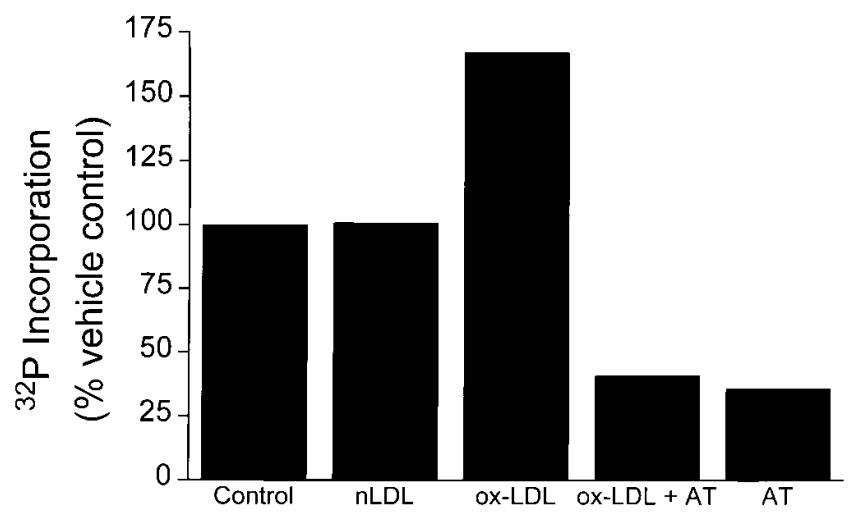

Figure 8. The effect of $\alpha$-tocopherol on HAEC protein kinase C stimulation by ox-LDL. HAECs were loaded with $\alpha$-tocopherol $(A T)$ or vehicle for $3 \mathrm{~d}$, washed, and incubated with ox-LDL $(300 \mu \mathrm{g} / \mathrm{ml})$, $\mathrm{nLDL}(300 \mu \mathrm{g} / \mathrm{ml})$, or media alone (control) for $4 \mathrm{~h}$. Cells were then washed three times with HBSS and protein kinase $\mathrm{C}$ activity determined as described in Methods. Results are representative of three independent experiments. 
tion. Endothelial dysfunction due to ox-LDL has, in part, been attributed to protein kinase $\mathrm{C}$ stimulation and we found that vascular $\alpha$-tocopherol incorporation limited endothelial dysfunction in response to PMA, a direct activator of protein kinase C. Using cultured HAECs, we confirmed that ox-LDL stimulates endothelial cell protein kinase $\mathrm{C}$ and that cellular incorporation of $\alpha$-tocopherol inhibits this protein kinase $\mathrm{C}$ stimulation.

Previous work from this (23) and other (39-41) laboratories has demonstrated that $\alpha$-tocopherol preserves normal endothelium-dependent arterial relaxation in experimental hypercholesterolemia and atherosclerosis. We have found that cholesterol-fed rabbits treated with 110 IU/d $\alpha$-tocopherol demonstrate preserved endothelium-dependent arterial relaxation compared with animals consuming no supplemental antioxidant (23). Änggård and co-workers have confirmed these findings and reported that dietary supplementation with $0.2 \%$ $\alpha$-tocopherol produced a striking improvement in coronary (40) and carotid (41) vasomotor responses to acetylcholine in cholesterol-fed rabbits. Similarly, Raij and colleagues found that Dahl salt-sensitive rats fed a high-cholesterol diet developed impaired endothelium-dependent arterial relaxation only if the animals were simultaneously deficient in vitamin $\mathrm{E}$ and selenium (39).

The precise mechanism(s) responsible for the effect of $\alpha$-tocopherol on endothelium-dependent arterial relaxation in experimental hypercholesterolemia and atherosclerosis is (are) not clear. Since ox-LDL produces impaired endothelium-derived NO action $(6,7)$ and $\alpha$-tocopherol inhibits LDL oxidation (14), it is attractive to speculate that $\alpha$-tocopherol preserves endothelium-dependent arterial relaxation simply by preventing LDL oxidation. We have, in fact, reported that $\alpha$-tocopherol (110 IU/d) preserved endothelium-dependent arterial relaxation in cholesterol-fed rabbits in association with protection of LDL against ex vivo copper-induced oxidation (23). However, we have additionally demonstrated that LDL isolated from cholesterol-fed rabbits consuming 1,100 IU/d of $\alpha$-tocopherol is also resistant to copper-induced oxidation although endothelium-dependent arterial relaxation is not preserved, but actually worsened (22). In light of these observations, it is unlikely that the protective effect of $\alpha$-tocopherol is solely due to the inhibition of LDL oxidation.

In this regard, $\alpha$-tocopherol has many potentially beneficial effects that are not strictly related to the antioxidant protection of LDL. For example, $\alpha$-tocopherol has been shown to inhibit leukocyte adhesion to endothelial cells (24), monocyte transmigration across the endothelium (25), smooth muscle cell proliferation (27), and oxidant-mediated cytotoxicity (26). These effects of $\alpha$-tocopherol appear dependent upon its cellular incorporation as a prolonged exposure of cells with $\alpha$-tocopherol is required (24-27).

The results reported here are consistent with the notion that tissue incorporation of $\alpha$-tocopherol provides beneficial vascular effects independent of LDL antioxidant protection. We found that vascular incorporation of $\alpha$-tocopherol was associated with significant protection against endothelial dysfunction due to ox-LDL (Fig. $3 A$ ). The importance of $\alpha$-tocopherol tissue incorporation is readily apparent from experiments demonstrating that incubation of $\alpha$-tocopherol-deficient arterial segments with $\alpha$-tocopherol ex vivo does not prevent endothelial dysfunction due to ox-LDL (Fig. 4). Additionally, the extent to which endothelium-dependent arterial relaxation was resistant to ox-LDL was directly related to the arterial content of $\alpha$-tocopherol $(R=0.67 ; P=0.0014)$. Thus, vascular incorporation of $\alpha$-tocopherol affords protection against oxLDL-mediated endothelial dysfunction.

ox-LDL is cytotoxic to cultured cells $(9,36)$ and $\alpha$-tocopherol is known to inhibit this cytotoxic effect of ox-LDL (36). One must consider that our results may primarily reflect a protective role of $\alpha$-tocopherol against cytotoxicity from ox-LDL. However, we found little evidence for significant cytotoxicity due to ox-LDL under the incubation conditions used here. For example, scanning electron microscopy revealed no significant change in endothelial cell morphology after vessel incubation with $500 \mu \mathrm{g} / \mathrm{ml}$ ox-LDL for $4 \mathrm{~h}$ (Fig. 5). In addition, vessel segments incubated with ox-LDL did not release significantly more LDH into the incubation medium than vessels incubated with nLDL (Table II). These results are consistent with cell culture experiments demonstrating significant cytotoxicity from ox-LDL only after 6-24 h of incubation (36).

Recent evidence has implicated protein kinase $\mathrm{C}$ activation in abnormal endothelium-dependent relaxation resulting from ox-LDL $(29,42)$. Moreover, $\alpha$-tocopherol is known to inhibit protein kinase $\mathrm{C}$ activation in vascular tissue (43) and cultured smooth muscle cells $(27,43)$. In this study, we found that PMA, a direct activator of protein kinase C (44), impaired receptor-mediated endothelium-dependent arterial relaxation in rabbit aorta from $\alpha$-tocopherol-deficient animals. In contrast, vessels derived from $\alpha$-tocopherol-supplemented animals were markedly more resistant to dysfunction from PMA (Fig. 6). These data are consistent with previous studies demonstrating that $\alpha$-tocopherol inhibits protein kinase $\mathrm{C}$ activation by phorbol esters (27).

Stimulation of protein kinase $\mathrm{C}$ is known to impair endothelium-dependent arterial relaxation and receptor-mediated stimulation of endothelial NO production. In isolated coronary arterial segments, Flavahan and colleagues demonstrated that protein kinase $\mathrm{C}$ stimulation with PMA produces impaired endothelium-dependent arterial relaxation that was mediated through a pertussis- toxin-sensitive G-protein (45) and, thus, was specific for receptor-mediated endotheliumdependent arterial relaxation. Our findings are consistent with these observations as PMA and ox-LDL treatment impaired the response to acetylcholine while leaving the response to A23187 largely unaffected (Figs. 2 and 6). One potential mechanism for consideration is protein kinase C-mediated phosphorylation of endothelial cell muscarinic receptors. Using chick hearts, Richardson and co-workers have demonstrated that muscarinic receptors are excellent substrates for protein kinase $\mathrm{C}$-mediated phosphorylation, a process that interrupts G-protein-dependent signal transduction (46). Thus, there is considerable evidence that protein kinase $\mathrm{C}$ stimulation impairs cholinergic receptor-mediated signal transduction similar to that observed in this study. Whether these findings can be generalized to other G-protein-dependent phenomena, however, remains to be determined.

With respect to endothelial cell NO production and bioactivity, other effects of protein kinase $\mathrm{C}$ stimulation also warrant consideration. Protein kinase $\mathrm{C}$ is known to directly phosphorylate the brain isoform of nitric oxide synthase (NOS1) resulting in a substantial reduction in activity (47). Whether PKC stimulation of endothelial cells results in phosphorylation of endothelial NOS (NOS3) remains to be determined. Inhibition of protein kinase $\mathrm{C}$ activity in bovine aortic endothelial 
cells is associated with increased NOS3 transcription (48), suggesting that PKC stimulation will reduce endothelial cell NOS protein. Finally, protein kinase $\mathrm{C}$ stimulation in vascular smooth muscle results in increased net vascular superoxide production that has the potential to impair endotheliumdependent arterial relaxation (49). We did not detect any increase in vascular superoxide production in ox-LDL-treated vessels (data not shown), suggesting that this latter effect of protein kinase $\mathrm{C}$ stimulation was not a prominent feature of our experimental preparation.

The precise mechanism(s) involved in protein kinase $\mathrm{C}$ inhibition by $\alpha$-tocopherol is (are) unclear. In vascular smooth muscle cells, inhibition of protein kinase $\mathrm{C}$ activity is not related to the antioxidant activity of $\alpha$-tocopherol (38). Other lipid-soluble antioxidants such as butylated hydroxytoluene (50) or tocotrienols (38) have no protein kinase C inhibitory activity. Boscoboinik and co-workers have found that the inhibitory effect of $\alpha$-tocopherol was concordant with its effect on PMA-stimulated protein kinase $\mathrm{C}$ activation and phosphorylation of the MARCKS (myristolated, alanine-rich C kinase substrate) protein (27). Moreover, these investigators found that $\alpha$-tocopherol upregulates phorbol ester binding while simultaneously increasing the cytosolic content of protein kinase $\mathrm{C}$ relative to the membrane content, suggesting that $\alpha$-tocopherol may inhibit protein kinase $\mathrm{C}$ translocation to the cell membrane. Recent observations that staurosporine, a microbial alkaloid and potent protein kinase $\mathrm{C}$ inhibitor, induces similar effects in human platelets (51) prompt speculation that these two compounds may inhibit protein kinase $\mathrm{C}$ by similar mechanisms.

In light of our observations that $\alpha$-tocopherol inhibits protein kinase $\mathrm{C}$ stimulation in endothelial cells, one might expect $\alpha$-tocopherol treatment to be universally beneficial. However, we have reported previously that cholesterol-fed rabbits receiving $110 \mathrm{IU} / \mathrm{d} \alpha$-tocopherol demonstrate preserved endothelial function while animals receiving 10 times this dose demonstrate impairment of endothelium-dependent arterial relaxation (22). The mechanism(s) responsible for this latter observation is (are) not yet clear. It is possible that extremely high tissue levels of $\alpha$-tocopherol (10-fold greater than that reported in the present study) result in other, as yet uncharacterized, effects that are not ameliorated by inhibition of protein kinase C stimulation. Such speculation, however, must be taken with some caution as these two studies are not entirely comparable. For example, the previous study involved cholesterol-fed animals and extremely high plasma and tissue $\alpha$-tocopherol levels (330 $\mu \mathrm{M}$ and $506 \mathrm{nmol} / \mathrm{gram}$ of tissue, respectively); both conditions were not a feature of the present study.

In summary, the incorporation of $\alpha$-tocopherol into the arterial wall is associated with protection against arterial dysfunction due to ox-LDL. The protection afforded by $\alpha$-tocopherol against the injurious action of ox-LDL was solely a function of the tissue $\alpha$-tocopherol content and was not related to the prevention of LDL oxidation by $\alpha$-tocopherol. Rather, this effect appears to result from inhibition of protein kinase $\mathrm{C}$ stimulation in the endothelial cell by ox-LDL. These data are consistent with the hypothesis that $\alpha$-tocopherol may, in part, be beneficial in hypercholesterolemia and atherosclerosis as a consequence of its tissue incorporation independent of the antioxidant protection of LDL.

\section{Acknowledgments}

We thank Stephanie Francis for technical assistance and Dr. Balz Frei for critical review of this manuscript.

This work was supported by grants from the Henckel Co., Fine Chemicals Division, and The Council for Tobacco Research, USA. J.A. Vita and J.F. Keaney, Jr. are recipients of Clinical Investigator Development Awards from the National Institutes of Health.

\section{References}

1. Furchgott, R.F., and J.V. Zawadzki. 1980. The obligatory role of endothelial cells in the relaxation of arterial smooth muscle by acetylcholine. Nature. (Lond.). 288:373-376.

2. Kelm, M., and J. Schrader. 1990. Control of coronary vascular tone by nitric oxide. Circ. Res. 66:1561-1575.

3. Azuma, H., M. Ishikawa, and S. Sekizaki. 1986. Endothelium-dependent inhibition of platelet aggregation. Br. J. Pharmacol. 88:411-415.

4. Ludmer, P.L., A.P. Selwyn, T.L. Shook, R.R. Wayne, G.H. Mudge, R.W. Alexander, and P. Ganz. 1986. Paradoxical vasoconstriction induced by acetylcholine in atherosclerotic coronary arteries. N. Engl. J. Med. 315:1046-1051.

5. Vita, J.A., C.B. Treasure, E.G., Nabel, J.M. McLenachan, R.D. Fish, A.C. Yeung, V.I. Vekshtein, A.P. Selwyn, and P. Ganz. 1990. Coronary vasomotor response to acetylcholine relates to risk factors for coronary artery disease. Circulation. 81:491-497.

6. Kugiyama, K., S.A. Kerns, J.D. Morrisett, R. Roberts, and P.D. Henry. 1990. Impairment of endothelium-dependent arterial relaxation by lysolecithin in modified low-density lipoproteins. Nature (Lond.). 344:160-162.

7. Chin, J.H., S. Azhar, and B.B. Hoffman. 1992. Inactivation of endothelium-derived relaxing factor by oxidized lipoproteins. J. Clin. Invest. 89:10-18.

8. Ylä-Herttuala, S., W. Palinski, M.E. Rosenfeld, S. Parthasarathy, T.E. Carew, S. Butler, J.L. Witztum, and D. Steinberg. 1989. Evidence for the presence of oxidatively modified low density lipoprotein in atherosclerotic lesions of rabbit and man. J. Clin. Invest. 84:1086-1095.

9. Morel, D.W., G.M. Hessler, and G.M. Chisolm. 1983. Low density lipoprotein cytotoxicity induced by free radical peroxidation of lipid. J. Lipid Res. 24:1070-1076.

10. Quinn, M.T., S. Parthasarathy, L.G. Fong, and D. Steinberg. 1987. Oxidatively modified low density lipoproteins: a potential role in recruitment and retention of monocyte/macrophages during atherogenesis. Proc. Natl. Acad. Sci. USA. 84:2995-2998.

11. Gryglewski, R.J., R.M. Palmer, and S. Moncada. 1986. Superoxide anion is involved in the breakdown of endothelium-derived vascular relaxing factor. Nature (Lond.). 320:454-456.

12. Burton, G.W., A. Joyce, and K.U. Ingold. 1983. Is vitamin E the only lipid-soluble, chain-breaking antioxidant in human plasma and erythrocyte membranes? Arch. Biochem. Biophys. 221:281-290.

13. Reaven, P.D., A. Khouw, W.F. Beltz, S. Parthasarathy, and J.L. Witztum. 1993. Effect of dietary antioxidant combinations in humans. Protection of LDL by vitamin E but not beta carotene. Arteriosclerosis Thromb. 13:590-600.

14. Dieber-Rotheneder, M., H. Puhl, H. Waeg, G. Striegl, and H. Esterbauer. 1991. Effect of oral supplementation with D-alpha-tocopherol on the vitamin E content of human low density lipoproteins and resistance to oxidation. J. Lipid Res. 32:1325-1332.

15. Riemersma, R.A., D.A. Wood, C.C.H. Macintyre, R.A. Elton, K.F. Gey, and M.F. Oliver. 1991. Risk of angina pectoris and plasma concentrations of vitamins A, C, E, and carotene. Lancet. 337:1-5.

16. Rimm, E.B., M.J. Stampfer, A. Ascherio, E. Giovannucci, G.A. Colditz, and W.C. Willett. 1993. Vitamin E consumption and the risk of coronary heart disease in men. N. Engl. J. Med. 328:1450-1456.

17. Stampfer, M.J., C.H. Hennekens, J.E. Manson, G.A. Colditz, B. Rosner, and W. Willett. 1993. Vitamin E consumption and the risk of coronary disease in women. N. Engl. J. Med. 328:1444-1449.

18. Witztum, J.L., and D. Steinberg. 1991. Role of oxidized low density lipoprotein in atherogenesis. J. Clin. Invest. 88:1785-1792.

19. Steinbrecher, U.P., S. Parthasarathy, D.S. Leake, J.L. Witztum, and D. Steinberg. 1984. Modification of low density lipoprotein by endothelial cells involves lipid peroxidation and degradation of low density lipoprotein phospholipids. Proc. Natl. Acad. Sci. USA. 81:3883-3887.

20. Verlangieri, A.J., and M.J. Bush. 1992. Effects of d-alpha-tocopherol supplementation on experimentally induced primate atherosclerosis. J. Am. Coll. Nutr. 11:131-138.

21. Godfried, S.L., G.F. Combs, J.M. Saroka, and L.A. Dillingham. 1989. Potentiation of atherosclerotic lesions in rabbits by a high dietary level of vitamin E. Br. J. Nutr. 61:607-617.

22. Keaney, J.F., Jr., J.M. Gaziano, A. Xu, B. Frei, J. Curran-Celentano, G.T. Shwaery, J. Loscalzo, and J.A. Vita. 1994. Low-dose $\alpha$-tocopherol improves and high-dose $\alpha$-tocopherol worsens endothelial vasodilator function in 
cholesterol-fed rabbits. J. Clin. Invest. 93:844-851.

23. Keaney, J.F., Jr., J.M. Gaziano, A. Xu, B. Frei, J. Curran-Celantano, G.T. Shwaery, J. Loscalzo, and J.A. Vita. 1993. Dietary antioxidants preserve endothelium-dependent vessel relaxation in cholesterol-fed rabbits. Proc. Natl. Acad. Sci. USA. 90:11880-11884.

24. Faruqi, R., C. de la Motta, and P. DiCorleto. 1994. Alpha-tocopherol inhibits agonist-induced monocytic cell adhesion to cultured human endothelial cells. J. Clin. Invest. 94:592-600.

25. Navab, M., S.S. Imes, S.Y. Hama, G.P. Hough, L.A. Ross, R.W. Bork, A.J. Valente, J.A. Berliner, D.C. Drinkwater, H. Laks, and A.M. Fogelman. 1991. Monocyte transmigration induced by modification of low density lipoprotein in cocultures of human aortic wall cells is due to induction of monocyte chemotactic protein 1 synthesis and is abolished by high density lipoprotein. $J$. Clin. Invest. 88:2039-2046.

26. Hennig, B., C. Enoch, and C.K. Chow. 1987. Protection by vitamin E against endothelial cell injury by linoleic acid hydroperoxides. Nutr. Res. 7: $1253-1260$.

27. Boscoboinik, D., A. Szewczyk, C. Hensey, and A. Azzi. 1991. Inhibition of cell proliferation by $\alpha$-tocopherol. J. Biol. Chem. 266:6188-6194.

28. Tesfamariam, B., M.L. Brown, and R.A. Cohen. 1991. Elevated glucose impairs endothelium-dependent relaxation by activating protein kinase C. $J$. Clin. Invest. 87:1643-1648.

29. Ohgushi, M., K. Kugiyama, K. Fukunaga, T. Murohara, S. Sugiyama, E. Miyamoto, and H. Yasue. 1993. Protein kinase C inhibitors prevent impairment of endothelium-dependent relaxation by oxidatively modified LDL. Arteriosclerosis Thromb. 13:1525-1532.

30. Chung, B.H., J.P. Segrest, M.J. Ray, J.D. Brunzell, J.E. Hokanson, R.M. Krauss, K. Beaudrie, and J.T. Cone. 1986. Single vertical spin density gradient ultracentrifugation. Methods Enzymol. 128:181-209.

31. Lowry, O.H., N.J. Rosebrough, A.L. Farr, and R.J. Randall. 1951. Protein measured with the Folin phenol reagent. J. Biol. Chem. 193:265-275.

32. Lynch, S.M., J.D. Morrow, L.J. Roberts II, and B. Frei. 1994. Formation of noncyclooxygenase-derived prostanoids ( $\mathrm{F}_{2}$-isoprostanes) in plasma and low-density lipoprotein exposed to oxidative stress in vitro. J. Clin. Invest. 93: 998-1004.

33. Stocker, R., V.W. Bowry, and B. Frei. 1991. Ubiquinol-10 protects human low density lipoprotein more efficiently against lipid peroxidation than does alpha-tocopherol. Proc. Natl. Acad. Sci. USA. 88:1646-1650.

34. Williams, B., and R.W. Schrier. 1992. Characterization of glucoseinduced in situ protein kinase $\mathrm{C}$ activity in cultured vascular smooth muscle cells. Diabetes. 41:1464-1472.

35. Keaney, J.F., Jr., and B. Frei. 1994. Antioxidant protection of low-density lipoprotein and its role in the prevention of atherosclerotic vascular disease. In Natural Antioxidants in Human Health and Disease. B. Frei, editor. Academic Press, San Diego. 303-352.

36. Reid, V.C., and M.J. Mitchinson. 1993. Toxicity of oxidised low density lipoprotein towards mouse peritoneal macrophages in vitro. Atherosclerosis. 98 : $17-24$

37. Mahoney, C.W., and A. Azzi. 1988. Vitamin E inhibits protein kinase C activity. Biochem. Biophys. Res. Commun. 154:694-697.
38. Chatelain, E., D.O. Boscoboinik, G.M. Bartoli, V.E. Kagan, F.K. Geiy, L. Packer, and A. Azzi. 1993. Inhibition of smooth muscle cell proliferation and protein kinase $\mathrm{C}$ activity by tocopherols and tocotrienols. Biochim. Biophys. Acta. 1176:83-89.

39. Raij, L., J. Jagy, K. Coffee, and E.G., DeMaster. 1993. Hypercholesterolemia promotes endothelial dysfunction in vitamin E- and selenium-deficient rats. Hypertension (Dallas). 22:56-61.

40. Andersson, T.L.G., J. Matz, G.A.A. Ferns, and E.E. Änggård. 1994. Vitamin $\mathrm{E}$ reverses cholesterol-induced endothelial dysfunction in the rabbit coronary circulation. Atherosclerosis. 111:39-45.

41. Stewart-Lee, A.L., L.A. Forster, J. Nourooz-Zadeh, G.A.A. Ferns, and E.E. Änggård. 1994. Vitamin E protects against impairment of endotheliummediated relaxations in cholesterol-fed rabbits. Arteriosclerosis Thromb. 14: 494-499.

42. Sugiyama, S., K. Kugiyama, M. Ohgushi, K. Fujimoto, and H. Yasue. 1994. Lysophosphatidylcholine in oxidized low-density lipoprotein increases endothelial susceptibility to polymorphonuclear leukocyte-induced endothelia dysfunction in porcine coronary arteries: role of protein kinase C. Circ. Res. 74: $565-575$.

43. Kunisaki, M., S.-E. Bursell, F. Umeda, H. Nawata, and G.L. King. 1994. Normalization of diacylglycerol-protein kinase $\mathrm{C}$ activation by vitamin $\mathrm{E}$ in aorta of diabetic rats and cultured rat smooth muscle cells exposed to elevated glucose levels. Diabetes. 43:1372-1377.

44. Castagna, M., M.Y. Takai, K. Kaibuchi, K. Sano, U. Kikkawa, and Y. Nishizuka. 1982. Direct activation of calcium-activated phospholipid-dependent protein kinase by tumor promoting phorbol esters. J. Biol. Chem. 257: 7847-7851.

45. Flavahan, N.A., H. Shimokawa, and P.M. Vanhoutte. 1991. Inhibition of endothelium-dependent relaxations by phorbol myristate acetate in canine coronary arteries: role of a pertussis toxin-sensitive G-protein. J. Pharmacol. Exp. Ther. 256:50-55.

46. Richardson, R.M., J. Ptasienski, and M.M. Hosey. 1992. Functional effects of protein kinase $\mathrm{C}$-mediated phosphorylation of chick heart muscarinic cholinergic receptors. J. Biol. Chem. 267:10127-10132.

47. Bredt, D.S., C.G. Ferris, and S.H. Snyder. 1992. Nitric oxide synthase regulatory sites: phosphorylation by cyclic AMP-dependent protein kinase, protein kinase $\mathrm{C}$, and calcium/calmodulin protein kinase; identification of flavin and calmodulin binding sites. J. Biol. Chem. 267:10976-10981.

48. Ohara, Y., H.S. Sayegh, J.J. Yamin, and D.G. Harrison. 1995. Regulation of endothelial constitutive nitric oxide synthase by protein kinase C. $\mathrm{Hy}$ pertension (Dallas). 25:415-420.

49. Ohara, Y., T.E. Peterson, B. Zheng, J.F. Kuo, and D.G. Harrison. 1994 Lysophosphatidylcholine increases vascular superoxide anion production via protein kinase C activation. Arteriosclerosis Thromb. 14:1007-1013.

50. Boscoboinik, D., A. Szewczyk, and A. Azzi. 1991. Alpha-tocopherol (vitamin E) regulates vascular smooth muscle cell proliferation and protein kinase C activity. Arch. Biochem. Biophys. 286:264-269.

51. Rais, S., C. Combadiere, J. Hakin, and A. Perianan. 1994. Staurosporine up-regulates the expression of phorbol dibutyrate binding sites in human platelets. Biochem. Pharmacol. 47:1797-1804. 